\title{
Pengaruh Program Edukasi Perawatan Kaki Berbasis Keluarga terhadap Perilaku Perawatan Kaki pada Pasien Diabetes Melitus Tipe 2
}

\author{
Citra Windani Mambang Sari, Hartiah Haroen, Nursiswati \\ Fakultas Keperawatan, Universitas Padjadjaran \\ Email:Ners_citra@yahoo.com
}

\begin{abstract}
Abstrak
Perilaku perawatan kaki merupakan komponen yang penting dalam pencegahan kaki diabetik. Namun, banyak pasien Diabetes Melitus (DM) yang tidak menjalankannya akibat rendahnya pengetahuan dan self-efficacy pasien maupun keluarga. Di sisi lain, dukungan dan keterlibatan keluarga merupakan aspek penting dalam terlaksananya perilaku perawatan kaki pasien DM. Pengembangan program peningkatan perawatan kaki DM berbasis keluarga penting dilakukan guna mengatasi kelemahan program sejenis yang berbasis individu. Tujuan penelitian ini adalah untuk mengidentifikasi pengaruh program edukasi perawatan kaki berbasis keluarga terhadap perilaku perawatan kaki pasien DM. Penelitian quasi experiment dengan pre-test and post-test with control group design ini melibatkan 72 responden DM Tipe 2 dan keluarganya yang diseleksi secara purposive dari populasi responden Diabetes Melitus di wilayah kerja Puskesmas Pasirkaliki Kota Bandung. Sampel dibagi menjadi kelompok intervensi dan kontrol dengan masing-masing 36 responden. Responden pada kelompok intervensi mendapatkan program edukasi perawatan kaki berbasis keluarga, konseling serta tindak lanjut 1 kali melalui telepon dan tiga kali melalui kunjungan langsung ke rumah. Perilaku perawatan kaki dikumpulkan menggunakan kuesioner. Data dianalisis menggunakan paired dan independent t-test. Hasil penelitian menunjukkan tidak ada perbedaan karakteristik antar kelompok. Perilaku perawatan kaki post test $(\mathrm{M}=84.69, \mathrm{SD}=4.49)$ pada kelompok intervensi berbeda secara bermakna $(p=0.000)$ lebih tinggi dibanding pre test $(\mathrm{M}=49.50, \mathrm{SD}=9.40)$, sedangkan pada kelompok kontrol ada penurunan skor setelah pengukuran (sebelum $\mathrm{M}=51,33, \mathrm{SD}=8,58$; sesudah $\mathrm{M}=49,50$, $\mathrm{SD}=9,40 ; \mathrm{p}=0,219$ ). Program edukasi perawatan kaki berbasis keluarga efektif meningkatkan perilaku perawatan kaki pasien DM. Dengan demikian, perawat dapat mengintegrasikan program edukasi perawatan kaki berbasis keluarga ke program perkesmas sebagai upaya pencegahan kaki diabetik pada pasien Diabetes Melitus.
\end{abstract}

Kata kunci : Diabetes Melitus, keluarga, perilaku perawatan kaki.

\section{Effectiveness of Family Based Foot Care Education Program towards Foot Care Behavior of Type 2 Diabetes Mellitus Patients}

\begin{abstract}
Foot care is an important behavior to prevent diabetic foot. However, many Diabetes Mellitus (DM) who have not performed the foot care due to lack of knowledge and the low self-efficacy of patients and their families. Support and involvement of families are important aspects in helping patients performing the foot care. Hence, the development of family based foot care education program is important in order to overcome the weaknesses of individual health education program. This study aimed to identify effectiveness of family based foot care education program towards the foot care behavior of DM patients. Quasi experiment using pre-and prost test with control group design was conducted involving 72 type 2 DM patients and their families which purposively selected from the population of DM patients in working area of Puskesmas Pasirkaliki Kota Bandung. Samples were divided into intervention and control groups, each group consists of 36 patients. Patients in the intervention group received family based foot care education program, counselling and a follow up through phone call, and three time home visits. The foot care behavior data were collected using questionnaires. Data were analyzed using paired and independent $t$-test. The results showed that there were no any difference of inter-group characteristics. The post-test foot care behavior in intervention group $(\mathrm{M}=84.69, \mathrm{SD}=4.49)$ was significantly higher compared to the pre-test score $(\mathrm{M}=49.50, \mathrm{SD}=9.40)$ $(\mathrm{p}=0.000)$. Meanwhile, in the control group, there was a decreased of behavior scores at the post test (pre-test $\mathrm{M}=51,33, \mathrm{SD}=8,58$; post-test $\mathrm{M}=49,50, \mathrm{SD}=9,40 ; \mathrm{p}=0,219)$. Family based foot care education program is effective to increase foot care behavior among DM patients. Hence, nurses can use this education program as one of community health nursing interventions to prevent the incidence of foot diabetic among Diabetes Mellitus patients.
\end{abstract}

Keywords: Diabetes Mellitus, family-based intervention, foot care.. 
Citra Windani Mambang Sari: Pengaruh Program Edukasi Perawatan Kaki Berbasis keluarga

\section{Pendahuluan}

Diabetes melitus (DM) merupakan salah satu penyakit kronik yang butuh penanganan serius. International Diabetes Federation (IDF, 2014) mencatat pada tahun 2013 terdapat 382 juta orang di dunia yang menderita DM, diantaranya terdapat 175 juta yang belum terdiagnosis dan terancam secara progresif menjadi komplikasi tanpa disadari akibat tanpa pencegahan. Data pada tahun tersebut diperkirakan akan meningkat menjadi 592 juta orang yang akan menderita diabetes melitus di tahun 2035 (IDF, 2014). Di Indonesia pada tahun 2013 terdapat sekitar 12 juta penduduk yang mengalami diabetes melitus dan diantaranya hanya 3 juta orang yang terdiagnosis (Pusdatin Kemenkes RI, 2014). Berdasarkan hasil Riskesdas Kemenkes RI (2013) prevalensi diabetes melitus di Indonesia meningkat dari $1.1 \%$ menjadi $2.1 \%$ dibanding pada tahun 2007.

Selain jumlah yang terus bertambah, DM juga diketahui banyak menimbulkan komplikasi yang dibagi menjadi dua yaitu komplikasi akut dan komplikasi kronis. Komplikasi akut meliputi ketoasidosis diabetik, hiperosmolar non ketotik, dan hipoglikemia (Perkeni, 2011). Menurut Perkeni (2011) yang termasuk komplikasi kronik adalah makroangiopati, mikroangiopati dan neuropati. Neuropati adalah gangguan pada sistem saraf pada kaki dan alirah darah perifer. Gangguan ini yang merupakan pintu awal terjadinya kaki diabetik (diabetic foot).

Faktor-faktor yang menyebabkan terjadinya kaki diabetik adalah neuropati perifer, kelainan vaskuler, kontrol gula darah yang buruk, trauma berulang, dan kelainan struktur anatomi kaki (Adhiarta, 2011). Adanya neuropati perifer dan angiopati perifer, maka trauma ringan pun dapat menyebabkan ulkus pada pasien Diabetes Melitus. Ketidaktahuan klien dan keluarga menambah ulkus bertambah parah dan dapat menjadi gangren (Waspadji, 2007).

Penanganan ulkus diabetik masih menemui banyak kendala, baik dari tingkat keberhasilan maupun biaya. Bahkan, sebagian gangren mengalami kekambuhan (Ghanassia Villon, Thuan dit Dieudonné, Boegner, Avignon, \& Sultan, 2008). Gangren banyak menimbulkan komplikasi baik secara fisik, psikis, sosial, maupun finansial (Dorresjtein, 2010). Di Indonesia, data di Rumah Sakit Cipto Mangunkusumo tercatat sebanyak $25 \%$ penderita kaki diabetik mengalami amputasi dan $16 \%$ diantaranya meninggal dunia (Adhiarta, 2011). Maka dari itu, strategi terbaik pengelolaan kaki diabetik adalah melakukan pencegahan.

Salah satu upaya pencegahan kaki diabetik adalah perawatan kaki secara reguler(Adhiarta, 2011; Vatankhah, 2009; Khamseh \& Noudeh, 2009). Perawatan kaki secara reguler dinilai mudah dan bisa dilakukan oleh pasien secara mandiri. Meski demikian, banyak pasien yang tidak menjalankan perawatan kaki yg diharapkan. Dari dua studi perilaku perawatan kaki (Kulzer, Hermann, Reinecker, \& Haak, 2007; Khamseh, Vatankhah, \& Baradaran, 2007) dievaluasi hanya komponen perawatan kaki dalam hal memilih alas kaki yang tepat, memeriksa kondisi kaki, dan kulit pelembab kaki.

Penelitian tentang program edukasi perawatan kaki telah banyak dilakukan dengan banyak hasil pengukuran. Semua penelitian dilakukan pada pasien secara individual dengan setting di rumah sakit (Sae-Sia, Maneewat, \& Kurniawan, 2013; Vatankhah et al., 2009) dan di rumah (Corbett, 2003, Lincoln et al,. 2008). Keempat penelitian tersebut tidak ada yang melibatkan keluarga dalam melakukan edukasi perawatan kaki. Padahal, menurut Friedman (2010), keluarga dapat dilibatkan sebagai sasaran edukasi, karena keluarga dapat menjadi pendorong anggota keluarga yang lain untuk melakukan suatu perilaku sehat yang diharapkan. Di samping itu, beberapa komponen perawatan kaki dalam rentang perjalanan penyakit DM bisa jadi pasien tidak mampu lagi menjalankannya secara mandiri, baik akibat komplikasi retinopati, obesitas, nyeri sendi, maupun kendala fisik lainya (Singh, Armstrong, \& Lipsky, 2005). Dengan kata lain, keterlibatan keluarga untuk membantu pasien menjalankan perawatan kaki secara berkesinambungan menjadi sangat penting.

Keluarga juga bisa menjadi pengingat dan pemberi dukungan materiil maupun nonmateriil bagi pasien dalam menjalankan perawatan kaki yang diharapkan. Edukasi perawatan kaki DM dengan melibatkan keluarga juga sangat penting, mengingat 
Citra Windani Mambang Sari: Pengaruh Program Edukasi Perawatan Kaki Berbasis keluarga

DM merupakan penyakit herediter yang menyebabkan anggota keluarga sebagai kalangan berisiko. Keterlibatan anggota keluarga bisa menjadi bagian dari upaya pencegahan dan early exposure keluarga sebagai kelompok berisiko tentang penyakit DM dan pengelolaanya, terutama upaya pencegahan komplikasi kaki DM.

Meskipun banyak kelebihan keterlibatan keluarga dibanding individual based intervention, namun belum ada penelitian yang membuktikan bahwa keterlibatan keluarga memberi dampak positif pada perawatan kaki pasien DM. Berdasarkan fenomena tersebut, perlu diteliti lebih lanjut adakah pengaruh program edukasi perawatan kaki berbasis keluarga terhadap perilaku perawatan kaki pada pasien Diabetes Melitus Tipe 2 (DMT2) di Kota Bandung khususnya di Wilayah Kerja Puskesmas Pasirkaliki.

Tujuan dari penelitian ini adalah mengidentifikasi pengaruh dari program edukasi perawatan kaki berbasis keluarga terhadap perilaku perawatan kaki pada pasien DM di Wilayah Kerja Puskesmas Pasirkaliki Kota Bandung.

\section{Metode Penelitian}

Rancangan penelitian ini adalah quasi eksperimental dengan menggunakan desain penelitian dua kelompok (kelompok intervensi dankelompok kontrol). Sebanyak 72 responden dan keluarganya direkrut dari Puskesmas Pasir Kaliki secara purposive. Adapun kriteria inklusi pada penelitian ini yaitu (1) telah didiagnosa menderita DM tipe 2 oleh dokter, (2) tinggal bersama keluarga, (3) mampu menulis, membaca dan berbahasa Indonesia, (4). Masing-masing kelompok terdiri dari 36 responden yang dibagi berdasarkan undian menggunakan koin dan matching berdasarkan tipe keluarga, riwayat terjadinya kaki diabetik, adanya keluhan neuropati dan pernah atau tidak mendapatkan edukasi perawatan kaki diabetik. Jumlah sampel tersebut didasarkan pada perhitungan sample size menurut Cohen (1988), yaitu masing - masing kelompok minimal 35.

Instrumen untuk mengukur perilaku perawatan kaki memakai kuesioner NAFF(Nothingham Assessment of Fungtional
Footcare) yang dimodifikasi, diterjemahkan ke dalam Bahasa Indonesia dan digunakan pada penelitian (Sae-Sia et al., 2013). Jumlah pertanyaan sebanyak 31 dengan 4 pilihan jawaban yaitu setiap hari, sering, jarang dan tidak pernah. Komponen pertanyaan pada instrumen meliputi memeriksa kaki, menjaga kebersihan kaki, perawatan kuku kaki, pemilihan alas kaki, pencegahan cedera dan pengelolaan cedera pada kaki. Peneliti menambah 3 pertanyaan tentang pencegahan cedera pada kaki meliputi senam kaki, merokok dan melipat kaki. Penelitian Vatankhah et al. (2009) dibuktikan bahwa senam kaki, menghindari merokok dan melipat kaki dapat mengurangi risiko kejadian kaki diabetik.

Pre test dilakukan pada kelompok intervensi dan kelompok kontrol dengan metode wawancara berdasarkan kuesioner perawatan kaki. Kelompok intervensi mendapatkan program edukasi perawatan kaki berbasis keluarga selama 4 minggu. Minggu I, peneliti melakukan identifikasi perawatan kaki yang telah dilakukan dan memberikan edukasi perawatan kaki dengan cara melibatkan keluarga meliputi faktor resiko komplikasi kaki, cara membersihkan kaki, dan perawatan kuku dengan menggunakan media modul. Minggu II, peneliti memberikan edukasi lanjutan tentang pemilihan alas kaki, pencegahan dan pengelolaan cedera pada kaki kepada responden dan keluarga. Minggu III, peneliti melakukan tindak lanjut intervensi melalui telpon kepada keluarga dengan melakukan identifikasi perilaku perawatan kaki yang sudah dilakukan serta mengingatkan kepada pasien dan keluarga tentang materi edukasi perawatan kaki yang telah diberikan. Minggu IV dan Minggu V, peneliti berkunjung kerumah pasien, melakukan tatap muka dengan pasien dan keluarga, melakukan identifikasi tentang perawatan kaki yang dijalankan pasien, mengidentifikasi kesulitan yang dihadapi oleh pasien dalam menjalankan perawatan kaki serta melakukan observasi pada kebersihan kaki, perawatan kuku kaki dan pemilihan alas kaki. Minggu VI, peneliti melakukan evaluasi kembali tentang perawatan kaki dan melakukan observasi pada kebersihan kaki, perawatan kuku kaki dan pemilihan alas kaki. Setelah itu, peneliti melakukan post-test dengan menggunakan instrumen yang sama pada saat pre-test. Adapun kelompok kontrol 
Citra Windani Mambang Sari: Pengaruh Program Edukasi Perawatan Kaki Berbasis keluarga

mendapatkan intervensi rutin yang diberikan oleh petugas puskesmas.

Analisa data dilakukan menggunakan analisis deskriptif (frekuensi, mean, SD, dan persentase). Dikarenakan data berdistribusi normal, maka untuk uji inferensial dilakukan menggunakan analisis parametrik (Dahlan, 2009). Paired t-test digunakan untuk mengetahui perbedaan perilaku perawatan kaki sebelum dan sesudah intervensi, baik pada kelompok intervensi dan kelompok kontrol. Selanjutnya, untuk mengetahui perbedaan rata-rata perilaku perawatan kaki pada kelompok kontrol dengan kelompok intervensi dilakukan uji $t$ - test independent.

\section{Hasil Penelitian}

Tabel 1 menunjukkan sebagian besar responden pada kelompok intervensi dan kelompok kontrol $(66,7 \%)$ berusia di rentang 40-59 tahun, berjenis kelamin perempuan (intervensi $(72,2 \%)$ dan kontrol $(75 \%)$ dan telah menikah pada kelompok intervensi $(83.3 \%)$ dan kontrol (75\%). Sebagian besar responden tidak bekerja (kelompok intervensi
$(72,2 \%)$ dan kontrol (61,1\%)). Hampir semua responden mempunyai latar belakang bersekolah. Dari tabel 1, juga dapat dilihat antara kelompok intervensi dan kontrol mempunyai data demografi yang homogen ( $p$ $>0.05)$.

Tabel 2 menggambarkan karakteristik klinis dari responden. Dari tabel 2 sebagian responden mempunyai lama diabetes lebih dari 3 tahun pada kelompok intervensi $(55,6 \%)$ dan kelompok kontrol $(58,3 \%)$. Sebagian responden melakukan olah raga pada kelompok intervensi sebesar $80,4 \%$ dan kelompok kontrol 83,3\%. Sebagian besar responden $(69,4 \%)$ pada kedua kelompok mempunyai keluhan neuropati. Sebagian besar responden mempunyai penyakit penyerta pada kelompok intervensi (75\%) dan pada kelompok kontrol (66,7\%). Sebagian besar responden pada kelompok kontrol dan kelompok intervensi memiliki sensasi baik saat pemeriksaan monofilament pada kaki kanan dan kiri. Hampir seluruh responden pada kedua kelompok tidak mempunyai riwayat kaki diabetik $(94,4 \%)$. Hasil uji homogenitas karakteristik klinik responden adalah tidak terdapat perbedaan yang bermakna antara

Tabel 1 Distribusi Frekuensi dan Analisis Uji Homogenitas Karakteristik Responden pada Kelompok Intervensi dan Kelompok Kontrol di Wilayah Puskesmas Pasirkaliki Bandung ( $\mathbf{N}=72)$

\begin{tabular}{|c|c|c|c|c|c|c|c|}
\hline \multirow[t]{2}{*}{ No } & \multirow[t]{2}{*}{ Variabel } & \multicolumn{2}{|c|}{$\begin{array}{c}\text { Intervensi } \\
\quad(n=36)\end{array}$} & \multicolumn{2}{|c|}{$\begin{array}{c}\text { Kontrol } \\
(n=36)\end{array}$} & \multirow[t]{2}{*}{$\mathbf{X}^{2}$} & \multirow[t]{2}{*}{ Nilai $p$} \\
\hline & & f & $\%$ & f & $\%$ & & \\
\hline \multirow[t]{3}{*}{1} & Usia & & & & & & \\
\hline & $40-59$ tahun & 24 & 66,7 & 24 & 66,7 & $0,000^{\mathrm{a}}$ & 1,000 \\
\hline & $59-69$ tahun & 12 & 33,3 & 12 & 33,3 & & \\
\hline \multirow[t]{3}{*}{2} & Jenis Kelamin & & & & & & \\
\hline & Laki-laki & 10 & 27,8 & 9 & 25 & $0,071^{\mathrm{a}}$ & 0,789 \\
\hline & Perempuan & 26 & 72,2 & 27 & 75 & & \\
\hline \multirow[t]{3}{*}{3} & Status & & & & & & \\
\hline & Menikah & 30 & 83,3 & 27 & 75 & $0,758^{\mathrm{a}}$ & 0,384 \\
\hline & Janda/duda & 6 & 16,7 & 9 & 25 & & \\
\hline \multirow[t]{3}{*}{4} & Pekerjaan & & & & & & \\
\hline & Tidak bekerja & 22 & 72,2 & 26 & 61,1 & $0,317^{\mathrm{a}}$ & 1,000 \\
\hline & Bekerja & 14 & 27,8 & 10 & 38,9 & & \\
\hline \multirow[t]{3}{*}{6.} & Tingkat pendidikan & & & & & & \\
\hline & Tidak sekolah & 3 & 8,3 & 1 & 2,8 & $0,303^{\mathrm{a}}$ & 1,000 \\
\hline & Sekolah & 33 & 91,7 & 35 & 97,2 & & \\
\hline
\end{tabular}

Catatan : $\mathrm{a}=$ Chi-Square 
Citra Windani Mambang Sari: Pengaruh Program Edukasi Perawatan Kaki Berbasis keluarga

Tabel 2 Distribusi Frekuensi dan Analisis Uji Karakteristik Klinis Kelompok Intervensi dan Kelompok Kontrol di Wilayah Kerja Puskesmas Pasirkaliki Bandung (N=72)

\begin{tabular}{|c|c|c|c|c|c|c|c|}
\hline \multirow[t]{2}{*}{ No } & \multirow[t]{2}{*}{ Variabel } & \multicolumn{2}{|c|}{$\begin{array}{c}\text { Intervensi } \\
(\mathrm{n}=36)\end{array}$} & \multicolumn{2}{|c|}{$\begin{array}{l}\text { Kontrol } \\
(\mathrm{n}=36)\end{array}$} & \multirow[t]{2}{*}{$X^{2}$} & \multirow[t]{2}{*}{ Nilai $p$} \\
\hline & & f & $\%$ & f & $\%$ & & \\
\hline \multirow[t]{3}{*}{1} & Lama Diabetes & & & & & & \\
\hline & $<3$ tahun & 16 & 44,4 & 15 & 41,7 & $0,057^{\mathrm{a}}$ & 0,812 \\
\hline & (>) 3 tahun & 20 & 55,6 & 21 & 58,3 & & \\
\hline \multirow[t]{3}{*}{2} & Olahraga & & & & & & \\
\hline & Tidak Pernah & 7 & 19,4 & 6 & 16,7 & $0,094^{\mathrm{a}}$ & 0,759 \\
\hline & Olahraga & 29 & 80,4 & 30 & 83,3 & & \\
\hline \multirow[t]{3}{*}{3} & Riwayat merokok & & & & & & \\
\hline & Tidak pernah & 25 & 69,4 & 21 & 58,3 & $0,964^{\mathrm{a}}$ & 0,326 \\
\hline & Merokok & 11 & 30,6 & 15 & 41,7 & & \\
\hline \multirow[t]{3}{*}{4} & $\begin{array}{l}\text { Program Edukasi } \\
\text { perawatan kaki }\end{array}$ & & & & & & \\
\hline & Pernah & 0 & 0 & 0 & 0 & $0,000^{\mathrm{a}}$ & 1,000 \\
\hline & Tidak pernah & 36 & 100 & 36 & 100 & & \\
\hline \multirow[t]{3}{*}{5} & $\begin{array}{l}\text { Keluhan } \\
\text { neuropati }\end{array}$ & & & & & & \\
\hline & Ada & 25 & 69,4 & 25 & 69,4 & $0,000^{\mathrm{a}}$ & 1,000 \\
\hline & Tidak ada & 11 & 30,6 & 11 & 30,6 & & \\
\hline \multirow[t]{3}{*}{6.} & $\begin{array}{l}\text { Penyakit } \\
\text { penyerta }\end{array}$ & & & & & & \\
\hline & Ada & 27 & 75 & 24 & 66,7 & $0,605^{\mathrm{a}}$ & 0,405 \\
\hline & Tidak ada & 9 & 25 & 12 & 33,3 & & \\
\hline \multirow[t]{3}{*}{7} & $\begin{array}{l}\text { Monofilamen pada } \\
\text { kaki kanan }\end{array}$ & & & & & & \\
\hline & Sensasi baik & 26 & 72,2 & 29 & 80,6 & $0,693^{\mathrm{a}}$ & 0,405 \\
\hline & Sensasi tidak baik & 10 & 27,8 & 7 & 19,4 & & \\
\hline \multirow[t]{3}{*}{8} & $\begin{array}{l}\text { Monofilamen pada } \\
\text { kaki kiri }\end{array}$ & & & & & & \\
\hline & Sensasi baik & 26 & 72,2 & 29 & 80,6 & $0,693^{\mathrm{a}}$ & 0,405 \\
\hline & Sensasi tidak baik & 10 & 27,8 & 7 & 19,4 & & \\
\hline \multirow[t]{3}{*}{9} & $\begin{array}{l}\text { Riwayat kaki } \\
\text { diabetik }\end{array}$ & & & & & & \\
\hline & Tidak pernah & 34 & 94,4 & 34 & 94,4 & $0,000^{b}$ & 1,000 \\
\hline & Pernah & 2 & 5,6 & 2 & 5,6 & & \\
\hline
\end{tabular}

Catatan : $\mathrm{a}=$ Chi-Square, $\mathrm{b}=$ Fisher-Exact

kelompok kontrol dan intervensi dalam lama diabetes, olahraga, edukasi perawatan kaki, keluhan, penyakit penyerta, dan monofilament serta riwayat kaki diabetik $(\mathrm{p}>0.05)$.

Tabel 3 menjelaskan perbedaan rata-rata perilaku perawatan kaki pada kelompok intervensi, diketahui bahwa pada kelompok intervensi perilaku perawatan kaki setelah intervensi $(84,69)$ secara bermakna lebih tinggi $(\mathrm{p}=0,00)$ dibandingkan perilaku perawatan kaki sebelum intervensi $(48,31)$. Sebaliknya, rerata skor post test perilaku perawatan kaki pada kelompok Kontrol justru lebih rendah dari skor pre test. 
Citra Windani Mambang Sari: Pengaruh Program Edukasi Perawatan Kaki Berbasis keluarga

Tabel 3 Perbedaan Rata-rata Perilaku Perawatan Kaki Sebelum dan Sesudah Intervensi pada Kelompok Kontrol di Wilayah Kerja Puskesmas Pasirkaliki Kota Bandung

\begin{tabular}{|c|c|c|c|c|}
\hline \multirow[t]{2}{*}{ Variabel } & \multicolumn{2}{|c|}{ Kelompok Kontrol } & \multirow[t]{2}{*}{$\mathbf{t}$} & \multirow[t]{2}{*}{ Nilai $f_{l}$} \\
\hline & Sebelum Mean (SD) & Sesudah Mean (SD) & & \\
\hline Kelompok Kontrol $(\mathrm{n}=36)$ & $51,33(8,58)$ & $49,50(9,40)$ & 1,251 & 0,219 \\
\hline Kelompok Intervensi $(\mathrm{n}=36)$ & $48,31(10,36)$ & $84,69(4,49)$ & $-25,407$ & 0,000 \\
\hline
\end{tabular}

Tabel 4 Perbedaan Rata-rata Perilaku Perawatan Kaki (Foot Care Behavior) Sebelum dan Sesudah Intervensi pada Kelompok Kontrol dan Kelompok Intervensi di Wilayah Kerja Puskesmas Pasirkaliki Kota Bandung ( $=72)$

\begin{tabular}{lcccc}
\hline $\begin{array}{l}\text { Variabel Perawatan } \\
\text { Kaki }\end{array}$ & Kelompok Intervensi & Kelompok Kontrol & t & Nilai $\boldsymbol{p}$ \\
\cline { 2 - 3 } & Mean (SD) & Mean (SD) & & 0,181 \\
\hline Sebelum & $48,31(10,36)$ & $51,33(8,58)$ & 1,350 & 0,000 \\
Sesudah & $84,69(4,49)$ & $49,50(9,40)$ & $-20,264$ & 0 \\
\hline
\end{tabular}

Catatan $: \mathrm{t}=$ independent $t$-test, $\mathrm{df}=70$

Rata-rata nilai perilaku perawatan kaki sebelum dilakukan intervensi pada kelompok intervensi $(48,31+10,36)$ lebih rendah dibandingkan kelompok kontrol $(51.33+8.58)$, tetapi tidak terdapat perbedaan bermakna secara statistik. Selain itu, ratarata nilai post test kelompok intervensi $(84,69+4,49)$ ditemukan lebih tinggi secara signifikan $(\mathrm{p}=0,00)$ dibandingkan rata-rata nilai perawatan kaki pada kelompok kontrol $(p=0.000)$.

\section{Pembahasan}

Hasil penelitian ini menunjukkan bahwa program edukasi berbasis keluarga secara signifikan meningkatkan perilaku perawatan kaki pada responden. Hasil tersebut dibuktikan dengan hasil uji beda pada masing-masing kelompok yang menunjukkan perbaikan secara signifikan pada kelompok intervensi, dan sebaliknya justru terjadi penurunan pada kelompok kontrol. Selain itu, pengaruh intervensi berbasis keluarga juga dibuktikan dengan hasil analisis uji beda antar kelompok yang menunjukkan adanya perbedaan yang signifikan nilai rata-rata post test perawatan kaki kelompok intervensi (lebih baik) dibanding kelompok kontrol, meskipun ratarata nilai pre test perawatan kaki kelompok intervensi lebih rendah dibanding kelompok kontrol.

Ada beberapa hal yang mendukung peningkatan perilaku perawatan kaki pada pasien DM dalam penelitian ini; 1) dasar dari program edukasi perawatan kaki berbasis keluarga, 2) metode edukasi, 3) dukungan keluarga dan partnership, 4) keterlibatan aktif dari responden, 5) tindak lanjut program. Dasar dari program edukasi perawatan kaki berbasis keluarga ditopang oleh Interaction Model of Client Health Behavior yang diadaptasi dari Corbett (2003). Berdasarkan model tersebut, perilaku klien dibentuk dalam 3 elemen, yaitu karakteristik klien, karakteristik penyedia pelayanan dan elemen hasil layanan. Model ini biasa digunakan sebagai pendekatan dalam upaya peningkatan perilaku pasien dengan pada masalah ekstremitas bawah. Dari model tersebut, keluarga dalam penelitian ini menjadi bagian dari elemen yang memperkuat aspek responden. Penguatan dari pihak keluarga dikombinasi dengan pemberi pelayanan (peneliti sebagai pemberi intervensi) akan memperkuat komponen hasil layanan.

Pelibatan keluarga dalam penelitian ini dimaksudkan untuk meningkatkan dukungan keluarga terhadap pasien dalam menjalankan perilaku perawatan kaki yang diharapkan. Dukungan keluarga terhadap responden mempunyai peran penting dalam meningkatkan perilaku perawatan kaki. Salah satu faktor dasar pendukung yang dapat meningkatkan kemampuan individual adalah dukungan keluarga (Orem, 2001). Hasil penelitian sebelumnya menyatakan dukungan keluarga berpengaruh secara bermakna 
Citra Windani Mambang Sari: Pengaruh Program Edukasi Perawatan Kaki Berbasis keluarga

terhadap perilaku tingkat kemandirian pasien Diabetes Melitus (Susanti, dkk., 2012).

Keterlibatan keluarga dalam manajemen DM sangat diperlukan karena keluarga adalah pemberi asuhan (caregiver) utama selama pasien di rumah. Lingkungan keluarga bisa memberi pengaruh positif dalam upaya edukasi perilaku perawatan kaki kepada pasien Diabetes. Pasien DM diharapkan mampu menjalankan perawatan kaki DM secara mandiri. Meski demikian, seiring berjalannya waktu pasien DM banyak mengalami komplikasi akibat DM maupun dampak penuaan yang menghambat pasien tidak lagi mempu menjalankan perawatan kaki secara mandiri. Penelitian Singh, Armstrong, dan Lipsky (2005) menemukan bahwa obesitas, nyeri sendi dan gangguan penglihatan menghambat pasien menjalankan perawatan kaki secara mandiri. Pada kondisi ini, peran keluarga menjadi sangat krusial dalam memfasilitasi pasien menjalankan perawatan kaki yang diharapkan.

Keeratan pada anggota keluarga memengaruhi suasana keluarga di Indonesia. Nilai-nilai fungsi afeksi pada anggota keluarga yang memberikan pengaruh dalam memperbaiki dan meningkatkan perilaku perawatan kaki responden. Anggota keluarga yang terlibat dalam program edukasi perawatan kaki berbasis keluarga dipilih responden berdasarkan orang yang paling dekat dengan responden dan tinggal serumah. Dengan demikian, anggota keluarga dapat menjadi support system bagi pasien dalam menjalankan perilaku perawatan kaki.

Berbeda dengan hasil penelitian sebelumnya yang melaporkan peningkatan perilaku perawatan kaki pada 5 minggu (Sae-sia et al., 2013), selama 6 dan 12 minggu (Corbett, 2007), selama 6 bulan (Vatankhah et al, 2009), selama 12 bulan (Lincoln et al., 2008) setelah program edukasi individu dilakukan. Hasil penelitian ini dapat meningkatkan perilaku perawatan kaki hanya dengan 4 minggu setelah intervensi program edukasi perawatan kaki berbasis keluarga dilakukan. Hal ini membuktikan bahwa keterlibatan keluarga dapat mempercepat peningkatan perawatan kaki karena keterlibatan keluarga sebagai support sistem pada responden dalam menjalankan perilaku perawatan kaki.

Secara proses edukasi, edukasi berbasis keluarga dalam penelitian ini dijalankan secara berulang dan disertai follow-up. Diabetes-Self Management Education (DSME) merekomendasikan proses pendidikan kesehatan yang dilakukan untuk meningkatkan self management pasien DM harus dijalankan secara terus-menerus untuk mendapatkan pengetahuan, keterampilan, kemampuan yang diperlukan untuk perawatan mandiri diabetes (Funnel et al., 2004). Hal ini juga dikuatkan oleh Dorresteijn et al. (2010) yang menyatakan bahwa pendidikan kesehatan pada responden DM yang dijalankan secara terus-menerus sangat efektif memfasilitasi terjadinya perubahan perilaku perawatan kaki. Efek program edukasi berbasis keluarga menjadi signifikan, karena hampir seluruhnya responden pada kelompok intervensi lebih banyak berpendidikan.

Penggunaan modul yang berisi tentang perilaku perawatan kaki yang disertai gambar sebagai media edukasi juga akan meningkatkan efektifitas edukasi dalam memperbaiki perilaku. Menurut Sudiharto (2007), penyediaan bahan edukasi yang informatif dan menarik, sebagai pendukung yang sangat kuat dalam memberikan edukasi. Bahan edukasi perawatan kaki yang menarik, akan meningkatkan pemahaman dan menstimulasi antusiasme pasien dan keluarga dalam mengikuti pemaparan materi. Penelitian sebelumnya melaporkan bahwa penggunaan modul pada saat sesi pendidikan kesehatan efektif meningkatkan pengetahuan dan perilaku baik dalam jangka pendek (5 minggu) (Sae-Sia et al., 2013), maupun jangka panjang (6 bulan) (Vatankhah et al., 2009). Modul memungkinkan responden dan/keluarga untuk membaca ulang, mencari informasi lanjut terkait materi yang telah.

Program edukasi dalam penelitian ini dirangkai dengan pembuatan "therapeutic contract". Responden dan keluarga difasilitasi untuk mengambil keputusan domain perawatan kaki yang akan diperbaikinya serta merencanakan perilaku perawatan kaki untuk mencapai target yang disepakati sesuai dengan kemampuan responden. Sae-Sia et al (2013) mencatat bahwa goal setting (therapeutic contract) efektif membantu pasien mencapai perilaku yg lebih baik.

Di dalam modul terdapat self-report tentang perawatan kaki yang diisi oleh responden atau 
Citra Windani Mambang Sari: Pengaruh Program Edukasi Perawatan Kaki Berbasis keluarga

keluarga jika telah menjalani perawatan kaki. Self-report dibuat peneliti agar responden dan keluarga responden dapat meningkatkan kesadaran untuk melakukan perawatan kaki walaupun tidak disupervisi langsung setiap hari oleh peneliti. Pengisian self-report dimudahkan oleh peneliti, sehingga responden atau keluarga hanya memberikan tanda chek list pada kolom perilaku perawatan kaki yang sesuai.

Keterlibatan aktif dari responden Diabetes Melitus dan keluarga pada setiap intervensi mempunyai kontribusi dalam meningkatkan perilaku perawatan kaki yang lebih baik. Pasien mempunyai kesempatan untuk bertanya, bertukar pikiran antara anggota keluarga, pasien dan peneliti di setiap fase intervensi yang dilakukan. Hal ini dapat membangun komitmen dan kepercayaan diri pasien dalam melakukan perilaku perawatan kaki. Selain itu, program edukasi perawatan kaki berbasis keluarga ini mengizinkan pasien untuk mengekspresikan secara bebas hal hal yang menjadi hambatan dalam perilaku perawatan kaki. Hasil penelitian sebelumnya melaporkan bahwa keterlibatan aktif dari responden menghasilkan perilaku perawatan kaki yang lebih baik (Sae-Sia et al., 2013).

Komunikasi antara pasien, peneliti dan keluarga memperkuat implementasi dari program edukasi perawatan kaki berbasis keluarga. Strategi variasi komunikasi diaplikasikan di setiap intervensi program ini. Interaksi yang terus - menerus antara peneliti, responden dan anggota keluarga mempunyai pengaruh terhadap kondisi psikologis dari pasien.

Program edukasi perawatan kaki berbasis keluarga ini efektif juga didukung oleh adanya tindak lanjut 1 kali melalui telpon dan 3 kali kunjungan rumah. Penelitian sebelumnya melakukan tindak lanjut melalui telepon sebanyak 3 kali (Sae-sia et al., 2013) menunjukkan hasil signifikan. Tindak lanjut sangat penting untuk mengevaluasi perilaku perawatan kaki dan untuk membantu pasien mengatasi hambatan dalam melakukan perawatan kaki. Tindak lanjut melalui telpon berisi supervisi perilaku perawatan kaki yang sudah dan belum dijalankan. Peneliti menanyakan perilaku perawatan kaki yang sudah dijalankan serta menanyakan kesulitannya dalam menjalankan perawatan kaki. Selain itu, peneliti juga menanyakan tentang kesulitan dalam menjalalankan perilaku perawatan kaki yang belum dijalankan. Pada saat itu, peneliti memberikan konsultasi singkat guna menemukan solusi sehingga responden dapat menjalankan perilaku perawatan kakinya.

Kunjungan rumah dilakukan sebanyak 3 kali dengan metode supervisi langsung kepada responden. Peneliti menanyakan perilaku perawatan kaki yang sudah dijalankan dan memeriksa langsung kebersihan kaki dan kuku serta alas kaki yang dipakai responden. Selain itu, peneliti memberikan intervensi berupa motivasi pada responden agar melakukan perawatan kaki sesuai yang diharapkan. Pemberian intervensi motivasi juga diberikan kepada keluarga agar dapat mengingatkan responden untuk melakukan perawatan kaki.

Tindak lanjut melalui telpon dan kunjungan rumah yang regular dapat memfasilitasi responden untuk meningkatkan pengetahuan, tanggung jawab, keterampilan, dan motivasi secara berkelanjutan untuk memperbaiki perilaku perawatan kaki. Penelitian sebelumnya yang bertujuan merubah perilaku dan menerima tindak lanjut (berupa telpon, email dan kunjungan rumah yang berulang) yang mana responden juga mendapatkan respon terhadap perubahan, menghasilkan perubahan perilaku yang diharapkan dibanding dengan hanya bertujuan untuk perubahan perilaku tanpa ada tindak lanjut atau respon (Bodenheimer et al., 2007).

Komponen pemeriksaan kaki dan kebersihan kaki menunjukkan perilaku yang mengalami peningkatan karena berhubungan dengan agama. Seluruh responden pada kelompok intervensi adalah Muslim. Sebelum melaksanakan sholat, seorang Muslim harus mencuci kaki sekurang-kurangnya lima kali sehari yaitu dengan berwudhu. Jika dibandingkan dengan komponen perilaku perawatan kaki yang lain, kebersihan kaki dan pemeriksaan kaki secara rutin bagi responden merupakan hal yang mudah.

Program edukasi perawatan kaki berbasis keluarga selama 5 minggu ini dengan menggunakan kombinasi tindak lanjut menghasilkan peningkatan perilaku perawatan kaki yang efektif pada kelompok intervensi. Selanjutnya, pada akhir program, responden dan keluarga responden menyampaikan 
Citra Windani Mambang Sari: Pengaruh Program Edukasi Perawatan Kaki Berbasis keluarga

kepuasan dan manfaat dari program edukasi berbasis keluarga ini dan tidak ada satupun responden dan keluarga yang keluar dari program ini. Ini menandakan bahwa program ini dapat diimplementasikan tetapi tetap sesuai dengan konteks budaya Sunda, umumnya Indonesia.

Efek program edukasi berbasis keluarga dalam penelitian ini menjadi efektif karena karakteristik responden sebagian besar masih dalam usia madya (40-59 tahun) dan tidak bekerja. Hal ini dapat menjadikan sedikitnya penyulit melakukan perilaku perawatan kaki pada responden. Berbeda hasilnya jika dengan responden lebih banyak pada usia lansia dan bekerja. Lansia beresiko terjadinya gangguan penglihatan, dan dapat mengganggu perawatan kaki (Singh et al, 2005).

\section{Simpulan}

Penelitian ini bertujuan mengidentifikasi pengaruh edukasi berbasis keluarga terhadap perilaku perawatan kaki pasien Diabetes Melitus di Kota Bandung. Berdasarkan hasil penelitian dan pembahasan dapat disimpulkan bahwaprogramedukasiperawatankakiberbasis keluarga secara signifikan meningkatkan/ memperbaiki perilaku perawatan kaki pada pasien Diabetes Melitus tipe 2 di Wilayah Kerja Puskesmas Pasirkaliki Kota Bandung. Hasil penelitian dapat dijadikan sebagai dasar pengembangan program terkait upaya pencegahan kaki diabetik di Kota Bandung.

\section{Daftar Pustaka}

Adhiarta. (2011). Penatalaksanaan kaki diabetik. Artikel dalam Forum Diabetes Nasional $V$. Diterbitkan oleh Pusat Informasi Ilmiah Departemen Ilmu Penyakit Dalam FK Unpad. Bandung.

Bodenheimer, T., Davis C., \& Holman, H. 2007. Helping Patients adopt healthier behaviors. Clinical Diabetes, 25, 66-70.

Cohen, J. (1988). Statistical power analysis for the behavioral sciences. Lawrence Elrbraum Asssociates Inc. Publishers, New Jersey.
Corbett, C.F. (2003). A Randomized pilot study of improving foot care in home health patients with diabetes. The Diabetes Educator, 29, 273.

Dahlan, M.S. (2009). Statistik untuk kedokteran dan kesehatan. Jakarta: Salemba Medika.

Dorresteijn, J.A.N., Kriegsman, D.M.W., Assendelft, W.J.J., \& Valk, G.D. (2010). Patient education for preventing diabetic foot ulceration. The Cochrane Collaboration, 5. Available http://www.thecochranelibrary.com.

Friedman, M.M., Bowden, V.R., \& Jones, E.G. (2010). Buku ajar keperawatan keluarga: Riset, Teori, praktek. Jakarta: EGC.

Funnel, M.M., \& Anderson, R.M. (2004). Empowerment and Self Management of Diabetes. Clinical Diabetes, 22(3). Available: http://clinical.diabetesjournals.org/ content/22/3/123.full.pdf + html.

Ghanassia, E., Villon, L., Thuan dit Dieudonné, J. F., Boegner, C., Avignon, A., \& Sultan, A. (2008). Long-Term Outcome and Disability of Diabetic Patients Hospitalized for Diabetic Foot Ulcers. Diabetes Care, 31, 1288-1292.

International Diabetes Federation (IDF). (2014). International Diabetes Atlas. International Diabetes Federation

Kulzer, Hermanns, Reinecker, \& Haak. (2007). Effect of self-management training type 2 diabetes: A randomized, prospective trial. Diabetic Medicine, 24(4), 415-423.

Khamseh, M.E., Vatankhah, N., Baradaran, H.R. (2007). Knowledge and practice of foot care in iranian people with type 2 diabetes. International Wound Journal, 4(4).

Lincoln, N.B., Radford, K.A., Game, F.L., \& Jeffcoate, W.J. (2008). Education for secondary prevention of foot ulcers in people with diabetes: A randomized controlled trial. Diabetologia, 51, 1954-1961.

Orem. (2001). Nursing : Concept of Practice. St. Louis : Mosby Inc. 
Citra Windani Mambang Sari: Pengaruh Program Edukasi Perawatan Kaki Berbasis keluarga

Perkeni. (2011). Konsensus pengelolaan dan pencegahan diabetes melitus tipe 2 di Indonesia 2011. PB. Jakarta: Perkeni.

Pusdatin Kemenkes RI. (2014). Situasi dan analisis diabetes. Jakarta.

Sae-Sia, W., Maneewat, K., \& Kurniawan, T. (2013). Effect of a self-management support program on diabetic foot care behaviors. International Journal of Research in Nursing, $4(1), 14$.

Singh, N., Armstrong, D.G., \& Lipsky, B.A. (2005). Preventing foot ulcers in patient with diabetes. American Medical Association $J A M A$, 293(2). Avalable from jama.ama-assn. org.

Sudiharto. (2007). Asuhan keperawatan keluarga dengan menggunakan pendekatan keperawatan transkultural. Jakarta: EGC.
Susanti, S., Haroen, H., \& Juniarti, N. (2012). Pengaruh DSME (Diabetes Self-Management Education) berbasis keluarga terhadap tingkat kemandirian pasien diabetes melitus di Wilayah Kerja Puskesmas Pasirkaliki kota Bandung. Tesis. Fakultas Keperawatan Program Pasca Sarjana Universitas Padjadjaran (Tidak Dipublikasikan).

Waspadji, S. (2007). Kaki diabetes, Ilmu Penyakit Dalam (Jilid 3 Edisi 4) Aru W. Sudoyo, Bambang Setyohadi, Idrus Alwi, Marcelius Sumadibrata, Siti Setiadi (ed). Pusat Penerbitan Ilmu Penyakit Dalam Fakultas Kedokteran Universitas Indonesia. Jakarta.

Vatankhah, N., Khamseh, M.E., Noudeh, Y.J., Aghili, R., Baradaran, H.R., \& Haeri, N.S. (2009). The effectiveness of foot care education on people with type 2 diabetes in Tehran, Iran. Primary Care Diabetes, 3, 7377. 


\section{Indeks Penulis}

A

Aat Sriati, 255

Ani Haryani, 255

Anita Setyawati, 283

Arimbi Karunia Estri, 225

Ayu Prawesti, 225

B

Binahayati Rusyidi, 236

C

Citra Windani Mambang Sari, 305

Cholina Trisa Siregar, 274

D

Dewi Elizadiani Suza, 274

F

F Sri Susilaningsih, 255

H

Hartiah Haroen, 305

Henny Suzana Mediani, 293

Helmy Hazmi, 293

I

Irman Somantri, 248
Inas Alifi Karima, 213

Iyus Yosep, 293

K

Kurniawan Yudianto, 267

Kusnanto, 213

Kusman Ibrahim, 283

$\mathbf{N}$

Nidaa' A'diilah, 248

Nunung Nurwati, 236

Nursiswati, 305

$\mathbf{R}$

Retnayu Pradanie, 213

S

Sari Fatimah, 225

Setiawan, 274

T

Titin Mulyati, 283

Titis Kurniawan, 267

$\mathbf{Z}$

Zabidah Putit, 293 